\title{
Effects of Dietary Calcium Propionate Supplementation on Hypothalamic Neuropeptide Messenger RNA Expression and Growth Performance in Finishing Rambouillet Lambs
}

\author{
Oswaldo Cifuentes-Lopez ${ }^{1}$, Héctor A. Lee-Rangel ${ }^{1} * \mathbb{0}$, German D. Mendoza ${ }^{2}$, Pablo Delgado-Sanchez ${ }^{1}$, \\ Luz Guerrero-Gonzalez ${ }^{1}$, Alfonso Chay-Canul ${ }^{3}$, Juan Manuel Pinos-Rodriguez ${ }^{4}$, Rogelio Flores-Ramírez ${ }^{5}{ }^{\circledR}$, \\ José Alejandro Roque-Jiménez ${ }^{1}\left[\right.$ and Alejandro E. Relling ${ }^{6}[$
}

1 Facultad de Agronomía y Veterinaria, Centro de Biociencias, Universidad Autónoma de San Luis Potosí, San Luis Potosí 78321, Mexico; ruben.cifuentes@uaslp.mx (O.C.-L.); pablo.delgado@uaslp.mx (P.D.-S.); luz.guerrero@uaslp.mx (L.G.-G.); alejandro.roque@uaslp.mx (J.A.R.-J.)

2 Departamento de Producción Agrícola y Animal, Universidad Autónoma Metropolitana Xochimilco, Ciudad de México 04970, Mexico; gmendoza@correo.xoc.uam.mx

3 División Académica de Ciencias Agropecuarias, Universidad Juárez Autónoma de Tabasco, Tabasco 86040, Mexico; alfonso.chay@ujat.mx

4 Facultad de Medicina Veterinaria y Zootecnia, Universidad Veracruzana, Veracruz 91710, Mexico; jpinos@uv.mx

check for updates

Citation: Cifuentes-Lopez, O.; Lee-Rangel, H.A.; Mendoza, G.D.; Delgado-Sanchez, P.; GuerreroGonzalez, L.; Chay-Canul, A.; Pinos-Rodriguez, J.M.; FloresRamírez, R.; Roque-Jiménez, J.A.; Relling, A.E. Effects of Dietary Calcium Propionate Supplementation on Hypothalamic Neuropeptide Messenger RNA Expression and Growth Performance in Finishing Rambouillet Lambs. Life 2021, 11, 566. https://doi.org/10.3390/life11060566

Academic Editor: Chang-min Lee

Received: 3 May 2021

Accepted: 11 June 2021

Published: 16 June 2021

Publisher's Note: MDPI stays neutral with regard to jurisdictional claims in published maps and institutional affiliations.

Copyright: (c) 2021 by the authors. Licensee MDPI, Basel, Switzerland. This article is an open access article distributed under the terms and conditions of the Creative Commons Attribution (CC BY) license (https:/ / creativecommons.org/licenses/by/ $4.0 /)$.
5 CONACYT, Coordinación Para la Innovación y Aplicación de la Ciencia y la Tecnología (CIACYT), San Luis Potosi 78210, Mexico; rogelio.flores@uaslp.mx

6 Department of Animal Sciences, The Ohio State University, OARDC, Wooster, OH 44691, USA; relling.1@osu.edu

* Correspondence: hector.lee@uaslp.mx; Tel.: +52-444-852-4056

\begin{abstract}
The objective of this experiment was to evaluate the effects of feeding different levels concentrations of dietary calcium propionate ( $\mathrm{CaPr}$ ) on lambs' growth performance; ruminal fermentation parameters; glucose-insulin concentration; and hypothalamic mRNA expression for neuropeptide Y (NPY), agouti-related peptide (AgRP), and proopiomelanocortin (POMC). Thirtytwo individually fed lambs were randomly assigned to four treatments: (1) control diet $(0 \mathrm{~g} / \mathrm{kg}$ of CaPr), (2) low CaPr, (30 g/kg dry matter (DM)), (3) medium CaPr, (35 g/kg DM), and (4) high $\mathrm{CaPr}(40 \mathrm{~g} / \mathrm{kg} \mathrm{DM})$. After 42 days of feeding, lambs were slaughtered for collecting samples of the hypothalamus. Data were analyzed as a complete randomized design, and means were separated using linear and quadratic polynomial contrast. Growth performance was not affected $(p \geq 0.11)$ by dietary CaPr inclusion. The ruminal concentration of total volatile fatty acids (VFA) increased linearly $(p=0.04)$ as dietary CaPr increased. Likewise, a linear increase in plasma insulin concentration $(p=0.03)$ as dietary $\mathrm{CaPr}$ concentration increased. The relative mRNA expression of NPY exhibited a quadratic effect $(p<0.01)$, but there were significant differences in the mRNA expression of AgRP and POMC ( $p \geq 0.10)$. Dietary calcium propionate did not improve lamb growth performance in lambs feed with only forage diets. Intake was not correlated with feed intake with mRNA expression of neuropeptides.
\end{abstract}

Keywords: agouti-related peptide; calcium propionate; intake; neuropeptide Y; proopiomelanocortin; Rambouillet sheep

\section{Introduction}

Alternative sources of feedstuff should be evaluated to maximize energy intake in livestock production systems [1]. Calcium propionate ( $\mathrm{CaPr}$ ) serves as an energy source and may also act independently as metabolic mediator of nutritional status [2]. Feeding $\mathrm{CaPr}$ to ruminants would increase the concentration of propionate in the rumen. Propionate is the main precursor for glucose synthesis in the liver [3]. Calcium or sodium 
propionate have already been used in ruminant diets as replacers of grains or as energy supplements [4]. The addition of $30 \mathrm{~g}$ of CaPr per kilogram of dry matter (DM) in diets of lambs during the finishing period could increase the average daily weight gain (DWG) and rumen propionate concentration [5]. However, the excessive propionate absorption could lead to a decrease of dry matter intake (DMI) [6]. Even though approximately $85 \%$ of propionate is used for glucose production in lactating cows, propionate oxidation may also play a significant role in regulating DMI [7]. Sheperd and Combs [8] and Oba and Allen [9] observed an increase in plasma insulin and glucose concentration during ruminal propionate infusion in dairy cattle. Recently, there has been an increased interest in the identification of possible peripheral signals capable of linking metabolic or nutritional status to appetite neuroendocrine centers. Hormones such as leptin, ghrelin, and insulin can interact with appetite-regulating or neuroendocrine centers to regulate appetite centers. These hormones have shown their influence on various hypothalamic neuropeptides in different animal models, including sheep $[10,11]$. Neuropeptides known to increase appetite include neuropeptide $\mathrm{Y}$ (NPY) and agouti-related peptide (AgRP), while peptides derived from the propiomelanocortin (POMC) gene decrease appetite [12]. Hypothalamic mRNA expression for NPY and AgRP was greater in fasting sheep compared with those fed ad libitum [13]. Relling et al. [11] suggested that insulin may control DMI by regulating the hypotha-lamic gene expression of NPY, AgRP, and POMC in lambs. Additionally, Relling et al. [14], in an ex vivo experiment with ovine hypothalamus, reported the direct effects of insulin and glucose, but not propionate, on hypothalamic mRNA expression for the neuropeptides NPY, AgRP, or POMC.

On the basis of the previously cited literature, we hypothesized that CaPr supplementation in lambs feed with only forage diets reduces DMI, and the reduction of DMI is associated with changes in hypothalamic mRNA expression of NPY, AgRP, and POMC. The objectives in the current experiment were to evaluate the effects of increasing dietary concentrations of $\mathrm{CaPr}$ on growth performance and the concentrations of mRNA expression in the neuropeptides NPY, AgRP, and POMC.

\section{Materials and Methods}

\subsection{Ethics}

The Animal Care and Use Committee of the Veterinary and Animal Science Faculties from the Autonomous University of San Luis Potosí approved all procedures implemented in the present study (no. 004/25022015), which complied with regulations established by the Animal Protection Law and Sanitary Regulations enacted by the State of San Luis Potosí, México. All animal management procedures were conducted within the Federal guidelines of Mexican Government approved techniques for animal use and care (NOM051-ZOO-1995: humanitarian care of animals during mobilization; NOM-062-ZOO-1995: technical specifications for the care and use of laboratory animals-livestock farms; farms; centers of production, reproduction, and breeding; zoos; and exhibition halls must meet the basic principles of animal welfare; NOM-024-ZOO-1995: animal health stipulations and characteristics during transportation of animals; and NOM-033-ZOO-1995: humanitarian care and animal protection during slaughter). The current experiment was conducted at the Agronomy and Veterinarian Faculty of Autonomous University of San Luis Potosí Research Experimental Station, México.

\subsection{Animals and Diets}

Thirty-two individually fed Rambouillet male lambs (initial weight $27.93 \pm 4.6 \mathrm{~kg}$ ) were randomly assigned to one of four experimental diets ( $n=8$ per treatment): (1) a control $\operatorname{diet}(\mathrm{CONT}$ ) containing 93\% alfalfa hay, 7\% molasses, and no CaPr; (2) low CaPr (LCP) diet, which contained $30 \mathrm{~g} / \mathrm{kg}$ dry matter (DM) in control diet; (3) medium CaPr (MCP) diet, which contained $35 \mathrm{~g} / \mathrm{kg}$ DM in control diet; and (4) high $\mathrm{CaPr}(\mathrm{HCP})$ diet, which contained $40 \mathrm{~g} / \mathrm{kg}$ DM in control diet (Table 1). Alfalfa hay was replaced for the incorporation of CaPr. These doses were selected on the basis of results of previous studies in which increased 
doses of CaPr improved growth performance in lambs [1,5]. Diet was offered as a total mixed ration. The lambs were housed in individual cages equipped with feed and water bowls. Feed was provided at 8:00 and 15:00 h. After 10 days of adaptation (without CaPr), the lambs were fed with their experimental diets for 42 days. All lambs had free access to feed, and $100 \mathrm{~g}$ per kg extra of previous day DMI was offered to ensure $10 \%$ feed refusal.

Table 1. Experimental diets and chemical composition.

\begin{tabular}{|c|c|c|c|c|}
\hline & \multicolumn{4}{|c|}{ Calcium Propionate ${ }^{1}$ g/kg (DM) } \\
\hline & 0 & 30 & 35 & 40 \\
\hline \multicolumn{5}{|c|}{ Ingredient, $\mathrm{g} / \mathrm{kg} \mathrm{DM}$} \\
\hline Alfalfa hay, ground & 930 & 900 & 895 & 890 \\
\hline Molasses cane & 70 & 70 & 70 & 70 \\
\hline Calcium propionate & 0 & 30 & 35 & 40 \\
\hline \multicolumn{5}{|c|}{ Chemical composition (g/kg DM) } \\
\hline Dry matter & 905 & 900 & 898 & 899 \\
\hline Crude protein & 185 & 177 & 172 & 172 \\
\hline Ether extract & 24.3 & 24.4 & 21.8 & 21.7 \\
\hline Neutral detergent fiber & 539 & 542 & 515 & 506 \\
\hline Acid detergent fiber & 256 & 256.1 & 239.2 & 229.3 \\
\hline Ash & 9.14 & 9.21 & 9.81 & 11.1 \\
\hline
\end{tabular}

${ }_{1}^{1}$ Propionic acid $780 \mathrm{~g} / \mathrm{kg}$ and $\mathrm{Ca} 220 \mathrm{~g} / \mathrm{kg}$.

\subsection{Feed Analysis}

Daily samples of feed were collected and pooled every 14 days. Dry matter (ID 934.01) and total nitrogen (ID 984.13) in the diets were analyzed according to the AOAC [15] (Table 1). Neutral detergent fiber (aNDF) and acid detergent fiber (ADF) analyses were carried out according to Van Soest et al. [16]. Sodium sulfite and heat-stable amylase were used in analysis of aNDF. Results of both aNDF and ADF included residual ash (Table 1).

\subsection{Growth Performance, Blood, and Tissue Sampling}

As previously described, lambs were fed with the experimental diets for 42 days. The DMI was calculated daily by the difference between the amount of feed offered and the feed refusal. Lambs were weighed at the beginning (day 1) and at the end (day 42) of the experiment to evaluate body weight (BW) and estimate Average daily gain (ADG). Feed conversion (G:F) was expressed as the ratio of DMI to ADG. On day 42 at 07:00 h, blood samples $(8 \mathrm{~mL})$ were collected via venipuncture of the jugular vein with a lithium heparin vacutainer and a $20 \mathrm{G}$ needle, and blood samples were placed on ice and then centrifuged at $3500 \mathrm{rpm}$ for $15 \mathrm{~min}$ at $4{ }^{\circ} \mathrm{C}$ to obtain plasma. Plasma samples were aliquoted and stored in a freezer $\left(-20^{\circ} \mathrm{C}\right)$ for further analyses. After the blood sampling, lambs were euthanized by captive bolt and exsanguinated. Feed deprivation was imposed for $12 \mathrm{~h}$ before slaughter. At the end of the finishing period, the blood samples were taken, and the lambs were sent to the commercial abattoir [17]. After slaughter, the top of the skull was removed using a hand saw, and the hypothalamus was removed using a scalpel, as described by Glass et al. [18]. Briefly, the frontal landmark for the hypothalamus was the optic chiasm. The first incision was a 1.2-cm lateral cut behind the optic chiasm, and two $1.5 \mathrm{~cm}$ frontal-caudal cuts were made parallel to the third ventricle. A fourth cut was close to the rectangular area. A final cut was made at a depth of $0.6 \mathrm{~cm}$ to provide a cube-shaped tissue sample with dimensions of $1.2 \times 1.5 \times 0.6 \mathrm{~cm}^{3}$. The hypothalamic tissues were placed into in cryovials, flash-frozen in liquid nitrogen, and stored at $-80{ }^{\circ} \mathrm{C}$ until their analysis of relative mRNA expression. 


\subsection{Rumen Fermentation}

Rumen fluid $(50 \mathrm{~mL})$ was obtained directly from the cranial, ventral, and caudal areas after the slaughter of the animals. The three rumen fluid samples were mixed for $\mathrm{pH}$ determination ( $\mathrm{pH}$ meter Benchtop Cole Parmer 05669-20, Vernon Hills, IL, USA). Then, ruminal fluid was filtered through 4 layers of cheesecloth, and immediately acidified with $4 \mathrm{~mL}$ of $25 \%$ (wt/vol) metaphosphoric acid. The filtered ruminal fluid was centrifuged at $12,000 \times g$ for $10 \mathrm{~min}$. An aliquot of the supernatant was frozen $\left(-20^{\circ} \mathrm{C}\right)$ until further volatile fatty acids (VFA) analysis. Volatile fatty acid concentration was determined by chromatography on an Agilent HP-FFAP, $30 \mathrm{~mm} \times 0.25 \mathrm{~mm} \times 0.25$-mm column fused silica, installed in a gas chromatograph (Agilent 6890, Agilent United States, Santa Clara, CA, USA) by flame ionization detection and splitless injection. Volatile fatty acids from the rumen fluid were identified by comparison with retention times of known standards (Sigma Aldrich Canada) [19].

\subsection{Analytic Methods for Insulin and Glucose}

Plasma insulin concentration was measured using a commercial kit (Sigma Aldrich RAB0568. ELISA Kit, MO, USA). The range of the assay was 0.1 to $2.5 \mu \mathrm{g} / \mathrm{L}$. The inter-assay and intra-assay coefficients of variance were $7.0 \%$ and $4.4 \%$, respectively. Plasma glucose concentration was determinated using the glucose oxidase procedure [20].

\section{7. mRNA Expression Analysis}

To extract mRNA, the samples of hypothalamus were homogenized and isolated using the QuickRNA MiniPrep $\mathrm{Kit}^{\circledR}$ (Zimo Research Corp, Life Technologies, Inc., Carlsbad, CA, USA), including DNase treatment according to the manufacturer's specifications. Extracted mRNA from all samples was quantified using a BioTek Synergy 4 plate reader utilizing the Take3 system (BioTek U.S., Winooski, VT, USA) with all samples exhibiting an OD 260/280 between 1.8 and 2.0 and an OD 260/230 value between 1.8 and 2.2. Extracted mRNA integrity was assessed both visually by resolving $3 \mu \mathrm{L}$ RNA on a denaturing formaldehyde gel containing ethidium bromide and by determining an RNA Integrity Number (RIN) using a Bioanalyzer (Benchtop UV, Biodocit Imaging System, Transilluminator). For mRNA expression, One Step Real-time PCR was performed on the resulting extracted mRNA using a Step-One Plus Real-time PCR (Applied Biosystems) machine and Power SYBR ${ }^{\circledR}$ Green RNA-to-Ct Master Mix (Applied Biosystems, Foster City, CA, USA) according to the manufacturer's instructions. All PCR reactions were performed using sequence-specific primers (Table 2).

Table 2. Primer sequences used for the reverse transcriptase quantitative PCR.

\begin{tabular}{|c|c|c|}
\hline Item & Forward Sequence $5^{\prime}$ to $3^{\prime}$ & Reverse Sequence $5^{\prime}$ to $3^{\prime}$ \\
\hline NPY & 5'-CCC TTC TAT GTG GTG ATG GGA-3' & 5'-TGG GAG GAC TGG CAG ACT C-3' \\
\hline AgRP & $5^{\prime}$ - GAC CCG TGC GCC ACG TGC TAT-3' & 5'-GAG GAA CCT TCG CCC CTG CC-3' \\
\hline POMC & 5'-GCG CTA AGC CAAACG CCCCTT G-3' & 5'-GCCTTC GGG GTC AAC CTT CCG-3' \\
\hline${ }^{*} \mathrm{Cp}-\mathrm{B}$ & 5'-CGA GGT GGA GAAGCCCTT TGC C-3' & 5'-GGA GCC CTG TGG CGG GCT AT-3' \\
\hline
\end{tabular}

NPY, neuropeptide Y; AgRP, agouti-related peptide; POMC, proopiomelanocortin; * cyclophilin B as a housekeeping gene.

The housekeeping target gene Ovis aries peptidylprolyl isomerase B (cyclophilin B) was used to normalize the relative mRNA expression of neuropeptide Y (NPY), agouti-related neuropeptide (AgRP), and opiomelanocortin (POMC) [11,14]. The primers used in the current experiment were previously validated in ovine hypothalamus [11]. To confirm the presence and integrity of cDNA from PCR products, we performed validation by measuring the molecular weight of cDNA synthesis using a $2 \%$ at agarose gel electrophoresis. Fold change of mRNA expression of target genes was calculated according to $2^{-\Delta \mathrm{Ct}}$ method by Livak and Schmittgen [21], where $\Delta \mathrm{Ct}=\mathrm{CtTarget}-\mathrm{CtCp}-\mathrm{B}$. 


\subsection{Statistical Analyses}

Data were analyzed as a complete randomized design with the Proc Mixed of SAS (9.4, North Carolina, USA) [22]. The model included the fixed effect of the treatment and the random effect of lamb within treatment. Initial BW was used as a covariate only for the productive variables (final BW, ADG, DMI, and Feed conversion (FC)). Orthogonal polynomial contrasts were used to verify linear or quadratic effects for CaPr inclusion on lamb growth performance, ruminal fermentation parameters, plasma glucose, and insulin concentrations, as well as hypothalamic mRNA expression for $N P Y, A g R P$, and $P O M C$. Contrast coefficients for polynomial contrast were based on the unequal spacing of dosages between treatments (IML procedure of SAS). The $p$-value of 0.05 was selected as the significance level. Data are presented as LSmean and standard error of the mean (SEM).

\section{Results}

\subsection{Lamb Growth Performance and Rumen Fermentation}

Dietary CaPr addition into finishing lamb diets did not affect ( $p \geq 0.11$ ) final BW and ADG (Table 3). Although lambs fed diets with CaPr at 0, 30, 35, and $40 \mathrm{~g} / \mathrm{kg}$ DM with a daily intake of propionate at $0,172.8,205.6$, and $231.9 \mathrm{mmol}$, respectively, DMI was not affected ( $p \geq 0.12)$, and therefore, no hypophagic effects of CaPr were observed in the current experiment. Additionally, there was no difference for ADG ( $p \geq 0.54)$. There was no effect $(p \geq 0.14)$ of $\mathrm{CaPr}$ doses on ruminal $\mathrm{pH}$, butyrate, propionate, or acetate/propionate ratio. As CaPr concentration increased, total VFA increased linearly ( $p=0.04$; Table 3$)$, and the molar proportion of acetate decreased linearly $(p=0.01$; Table 3$)$.

Table 3. Growth performance and rumen traits of lambs fed with different levels of calcium propionate.

\begin{tabular}{|c|c|c|c|c|c|c|c|}
\hline \multirow{2}{*}{ Item } & \multicolumn{4}{|c|}{ Calcium Propionate ${ }^{1} \mathrm{~g} / \mathrm{kg}$ DM } & \multirow{2}{*}{ SEM $^{2}$} & \multicolumn{2}{|c|}{$p$-Value } \\
\hline & 0 & 30 & 35 & 40 & & $\mathbf{L}^{+}$ & $Q^{¥}$ \\
\hline \multicolumn{8}{|c|}{ Growth performance } \\
\hline Initial BW ${ }^{3}, \mathrm{~kg}$ & 25.1 & 28.4 & 27.6 & 28.6 & 0.33 & 0.55 & 0.42 \\
\hline Final BW, kg & 34.0 & 37.4 & 35.8 & 36.4 & 0.29 & 0.11 & 0.24 \\
\hline $\begin{array}{l}\text { Average daily gain } \\
\text { (ADG), } \mathrm{kg} / \mathrm{d}\end{array}$ & 0.221 & 0.223 & 0.204 & 0.195 & 0.01 & 0.53 & 0.64 \\
\hline $\begin{array}{l}\text { Dry matter intake (DMI), } \\
\mathrm{kg} / \mathrm{d}\end{array}$ & 1.57 & 1.49 & 1.52 & 1.50 & 0.04 & 0.38 & 0.32 \\
\hline $\begin{array}{c}\text { Feed conversion }(\mathrm{FC}) \\
\text { DWG/DMI }\end{array}$ & 7.6 & 7.1 & 7.5 & 7.9 & 0.87 & 0.79 & 0.58 \\
\hline \multicolumn{8}{|c|}{ Rumen fermentation } \\
\hline $\mathrm{pH}$ & 7.1 & 6.7 & 7.1 & 6.3 & 0.25 & 0.86 & 0.22 \\
\hline Total VFA ${ }^{4}, \mathrm{mmol} / \mathrm{L}$ & 35.4 & 65.9 & 61.0 & 73.6 & 6.60 & 0.04 & 0.14 \\
\hline Acetate, mol/100 mol & 69.1 & 66.2 & 67.1 & 66.1 & 0.86 & 0.01 & 0.15 \\
\hline Propionate, $\mathrm{mol} / 100 \mathrm{~mol}$ & 18.3 & 21.4 & 19.4 & 21.5 & 0.44 & 0.20 & 0.14 \\
\hline Butyrate, mol/100 mol & 12.6 & 12.4 & 13.5 & 12.4 & 0.11 & 0.11 & 0.21 \\
\hline Acetate/propionate ratio & 3.8 & 3.1 & 3.5 & 3.1 & 0.19 & 0.54 & 0.29 \\
\hline
\end{tabular}

${ }^{1}$ Propionic acid $780 \mathrm{~g} / \mathrm{Kg}$ and $\mathrm{Ca} 220 \mathrm{~g} / \mathrm{Kg} ;{ }^{2} \mathrm{SEM}$, standard error of the mean; ${ }^{3} \mathrm{BW}$, body weight; ${ }^{4} \mathrm{VFA}$, volatile fatty acids; $\mathrm{L}^{+}$, linear effect; $\mathrm{Q}^{¥}$, quadratic effect.

\subsection{Bloodstream Glucose-Insulin and Hypothalamic mRNA Expression}

There was no difference in plasma glucose concentration $(p \geq 0.40)$. However, there was a linear increase in plasma insulin concentration $(p=0.03)$ with increased of $\mathrm{CaPr}$ concentration in the diet (Table 4). Hypothalamic mRNA expression of NPY presented a quadratic effect $(p<0.01)$, but relative $A g R P$ and POMC mRNA expression were not affected $(p \geq 0.10$ ) by the increase of dietary CaPr supplementation (Table 4 ). 
Table 4. Effect of calcium propionate on bloodstream glucose-insulin, and concentrations and mRNA expression of appetite-regulating genes in the hypothalamus of Rambouillet lambs at day 43 of fattening.

\begin{tabular}{|c|c|c|c|c|c|c|c|}
\hline \multirow{2}{*}{ Item } & \multicolumn{4}{|c|}{ Calcium Propionate ${ }^{1} \mathrm{~g} / \mathrm{kg}$ DM } & & \multicolumn{2}{|c|}{$p$-Value } \\
\hline & 0 & 30 & 35 & 40 & SEM $^{2}$ & $\mathbf{L}^{+}$ & $Q^{¥}$ \\
\hline \multicolumn{8}{|c|}{ Plasma analysis } \\
\hline Glucose, $\mathrm{mg} / \mathrm{dL}$ & 97.66 & 100.66 & 102.21 & 59.4 & 6.33 & 0.40 & 0.53 \\
\hline Insulin, $\mu \mathrm{IU} / \mathrm{mL}$ & 2.0 & 2.24 & 2.03 & 12.56 & 1.71 & 0.03 & 0.62 \\
\hline \multicolumn{8}{|c|}{ Hypothalamic mRNA relative expression of genes } \\
\hline${ }^{3} \mathrm{NPY} / \mathrm{CYC}$ & 3.5 & 2.33 & 2.18 & 2.21 & 1.85 & 0.33 & 0.01 \\
\hline${ }^{4} \mathrm{AgRP} / \mathrm{CYC}$ & 3.69 & 2.42 & 3.25 & 2.06 & 0.96 & 0.10 & 0.34 \\
\hline${ }^{5} \mathrm{POMC} / \mathrm{CYC}$ & 3.89 & 3.67 & 3.55 & 3.33 & 0.28 & 0.39 & 0.88 \\
\hline
\end{tabular}

${ }^{1}$ Propionic acid $780 \mathrm{~g} / \mathrm{Kg}$ and $\mathrm{Ca} 220 \mathrm{~g} / \mathrm{Kg} ;{ }^{2} \mathrm{SEM}$, standard error of the mean; ${ }^{3} \mathrm{NPY}$, neuropeptide $\mathrm{Y} ;{ }^{4} \mathrm{AgRP}$ agouti-related peptide; ${ }^{5}$ POMC, pro-opiomelanocortin; $\mathrm{L}^{+}$, linear effect; $\mathrm{Q}^{¥}$, quadratic effect. ${ }^{*}$ Data were normalized by cyclophilin B mRNA quantification.

\section{Discussion}

As shown in Table 3, dietary CaPr addition into finishing lamb diets did not affect final BW and ADG. The results observed in the present study are not in contrast with that of previous studies [1,4]. Growth performance was also not affected by CaPr addition in the previous studies. Calcium propionate contains similar energy to propionic acid, which has a metabolizable energy content of $3.96 \mathrm{Mcal} / \mathrm{kg}$ of DM [1]. Alfalfa hay has been reported with $1.96 \mathrm{Mcal} / \mathrm{kg}$ of DM [23]. Thus, the substitution of alfalfa hay for CaPr should yield a greater ADG in growing lambs as described previously [5].

Likewise, Lee-Rangel et al. [4] and Mendoza-Martinez et al. [1] found no hypophagic effects of calcium propionate at a daily intake of 64.3 and $130.27 \mathrm{mmol}$ of propionate in finishing lambs, respectively. Hypophagic effects of propionate have been found more frequently when propionate was infused into rumen, portal, or mesenteric veins [24-26]. However, when propionate was included in diets, its hypophagic effect has been limited [27] or not shown [28-30]. Controversial effects of propionate on DMI have been related to differences in doses, diet quality (forage/concentrate proportion), physiological stage [9], and metabolic balance of the animal [2,31]. For example, hypophagic effects of propionate in dairy cows were more evident in early lactation than in later lactation [9]. This effect might be because a negative energy balance induces high mobilization of adipose tissue, as reported by Reynolds et al. [32]. Then, up to $70 \%$ of the propionic acid is extracted in the first pass through the liver [32].

There was no difference in DWG by the addition of CaPr into the lambs' diets (Table 3). Comparing the results from the current experiment, Lee et al. [4] and MartínezAispuro et al. [5] observed that the addition of 10 or $20 \mathrm{~g} / \mathrm{kg}$ DM of CaPr did not alter the ADG. However, Liu et al. [2] supplemented propionate directly in the rumen and observed an improve ADG in dairy cows. Cows supplemented with CaPr showed greater concentrations of plasma glucose [2]. These differences in DWG could be related to the improvement of energy balance and the changes in the concentration of plasma glucose.

No effected was observed on ruminal pH and VFA in the lambs supplemented with $\mathrm{CaPr}$ (Table 3). Fellner and Spears [33] and Grilli et al. [34] mentioned that some differences in VFA profile may be attributed to the dissociation of calcium propionate by the changes in the propionic acid proportion. The reduction of $\mathrm{pH}$ values by $\mathrm{CaPr}$ may be related to dissolved ruminal propionate, coinciding with previous studies with lambs $[1,4,35]$ and steers [33]. CaPr addition at the rate of $1 \%$ in the diet contributes only $0.003 \mathrm{mmol} / \mathrm{L}$ of propionic acid that could not be enough to have modified this variable in diets [35]. Nevertheless, an in vitro study showed that both $\mathrm{CaPr}$ and $\mathrm{CaCO}_{3}$ increased total VFA in ruminal cultures, but only CaPr increased ruminal propionate, butyrate, and valerate [33]. 
In one experiment with steers, supplemental $\mathrm{CaPr}$ resulted in greater proportions of propionate compared to $\mathrm{CaCO}_{3}[36]$.

Our results in Table 4 contrast with the concentration shown in other experimental animal studies for bloodstream glucose-insulin concentration. Rodrigues et al. [37] observed an increase in blood glucose concentration when ruminal propionate production increased. Moreover, Oba and Allen [9] described that lower rates of propionate infusion substantially increased plasma glucose concentration. We speculate that propionate is extensively used for glucose synthesis. However, our data showed a decrease in the concentration of plasma glucose with higher rates of $\mathrm{CaPr}$ addition - this could indicate that use of $\mathrm{CaPr}$ for gluconeogenesis decreases as the glucose demand of body tissues is satisfied.

A linear effect was observed in lambs where CaPr improved into the finishing diet (Table 4). The concentration of insulin responds to changes in the energetic metabolites in ruminants, regulating DMI [24]. Lemosquet et al. [38] reported that the infusion of propionate in the rumen increased the plasma insulin concentration without changing the plasma glucose concentration. Moreover, Liu et al. [2] showed a greater serum concentration of insulin in cows fed CaPr. Perhaps the increase in circulating propionate concentration served as a stimulus for glucose production and the secretion of insulin. Intraruminal infusion of VFA mixtures decreased plasma insulin concentration when propionate was not part of the mixture [39]. Finally, according to other experiments, gluconeogenic precursors may act through neuropeptides to stimulate secretion of insulin [11].

The inclusion of $\mathrm{CaPr}$ into finishing diets for lambs decreased the hypothalamic mRNA expression of NPY (Table 4). However, the CaPr supplementation did not affect the relative mRNA expression for $A g R P$ and POMC. For NPY to be considered an appetite regulator, it must also be capable of stimulating increased DMI of ad libitum-fed sheep. Intracerebroventricular (ICV) injection of NPY in sheep resulted in a pronounced increase in DMI [40]. This effect described for NPY to increase feed intake was also significant in the presence of rumen distention or propionate infusion [41]. Lee et al. [4] showed a decrease in NPY and $A g R P$ mRNA expression in mouse hypothalamic incubated with increasing concentrations of glucose with no changes in $P O M C$ concentrations in response to glucose. These effects of glucose on NPY and $A g R P$ expression in mice [4] support the glucostatic theory of feed intake regulation proposed by Mayer [42]. Previously, Relling et al. [11] reported the lack of an effect of glucose on NPY and $A g R P$ neuropeptide, and the authors mentioned that ruminants typically absorb a small amount of glucose, with plasma glucose concentrations being relatively constant and maintained primarily by liver synthesis from propionate, which shows little diurnal or postprandial variation. However, Relling et al. [11] described the role of glucose with insulin such as a whole factor to regulate the mRNA expression of neuropeptides NPY and $A g R P$. The signals that may influence the decrease in mRNA expression for NPY and $A g R P$ for ad libitum-fed lambs are increased plasma concentrations of insulin and cholecystokinin (CCK) or pre-feeding ghrelin [11]. It has been shown in rat models that central administration of insulin decreases NPY mRNA concentration [43]. Relling et al. [11] described that decreased hypothalamic mRNA expression of NPY and $A g R P$ in lambs results in an increase in consumption of metabolizable energy (ME), as well as the fact that the change in NPY mRNA could be related with an increase in plasma insulin concentration. However, Relling et al. [11] observed a decrease in mRNA relative expression for neuropeptides that stimulate DMI (NPY and $A g R P$ ) in lambs offered feed ad libitum compared with lambs whose intake was restricted.

In our experiment, we did not observe changes in DMI or BW attributable to the increase of $\mathrm{CaPr}$ in the diet. However, using previous data on CaPr energy efficiency [1], ME intake may be greater with a greater dose of Ca propionate. It could also be assumed that the increase in plasma insulin concentration in the current experiment is caused by an increase in ME intake. Mendoza-Martínez et al. [1] mention that the energy contribution of CaPr could be similar to that of propionic acid, and gross energy of $3.965 \mathrm{Mcal} / \mathrm{kg}$ can be estimated to ME of $3.766 \mathrm{Mcal} / \mathrm{kg}$. Values for ME were CONT $=3.81 \mathrm{Mcal} \mathrm{ME} / \mathrm{kg}$ 
$\mathrm{DM}, \mathrm{LCP}=3.63 \mathrm{Mcal} \mathrm{ME} / \mathrm{k} \mathrm{DM}, \mathrm{MCP}=3.70 \mathrm{Mcal} \mathrm{ME} / \mathrm{kg} \mathrm{DM}$, and HCP = 3.67 Mcal $\mathrm{ME} / \mathrm{kg}$ DM. Regulation of feed intake in this case is not mediated by ME intake, and the correlation between NPY mRNA abundance and ME intake was -0.30 . However, in our study, the association was between plasma insulin concentration and NPY mRNA concentration $(\mathrm{r}=0.35 ; p=0.25)$. Concentration of mRNA for $A g R P$ also increased in sheep with a low body condition score compared with sheep with a high body condition score [44]. Interestingly, feed restriction did not alter mRNA concentration for the AgRP [45]. Agoutirelated peptide increases appetite by inhibiting a receptor that inhibits appetite (or an inverse agonist). Injection of $A g R P$ into the lateral ventricle of ad libitum-fed sheep resulted in an increase in cumulative feed intake. The effect in DMI was present between 4 and

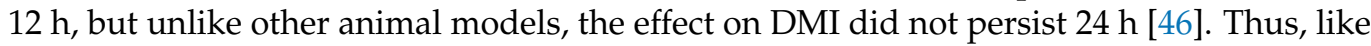
$N P Y$, this neuropeptide is clearly a factor in the regulation of DMI, an appetite regulator in sheep, and may provide a unique opportunity to manipulate appetite in disease, stress, and/or other metabolic problems related to a reduction in feed intake [47].

Relling et al. [11] reported that hypothalamic POMC mRNA concentration did not change as an effect of DMI (restricted vs. ad libitum-fed wethers). Moreover, Relling et al. [11,14] found that high glucose in the presence of insulin affects POMC expression, suggesting that under certain conditions glucose may have an effect on specific neuropeptides in ruminants, but that insulin is required to mediate such effect. The result in the current experiment may suggest that the interaction of insulin and glucose is required to modulate hypothalamic expression of POMC neuropeptide in ruminants, as observed in non-ruminants. Moreover, results from the current experiment joins to data to the few other experiments where the principal observation is that insulin concentration together with glucose concentration could be the key to modify the concentration of the neuropeptides NPY, AgRP, and POMC. Further investigation of the role of insulin together with glucose concentration in the hypothalamic expression of neuropeptides is needed.

\section{Conclusions}

The addition of calcium propionate to high forage diets did not modify the productive performance of lambs but changed the total rumen VFA profile. The dosage of $40 \mathrm{~g} / \mathrm{kg}$ decreased plasma glucose concentration and increased plasma insulin concentration. A greater insulin concentration could need a greater concentration of plasma glucose to modify the concentration of the neuropeptides NPY, AgRP, and POMC. Despite there was a decrease in NPY concentration when CaPr increase in the diet, the change in NPY mRNA expression is not associated with DMI.

Author Contributions: Conceptualization, O.C.-L., A.E.R. and H.A.L.-R.; methodology, O.C.-L., A.E.R., H.A.L.-R., L.G.-G. and P.D.-S.; software, H.A.L.-R.; validation, A.E.R., G.D.M., R.F.-R. and A.C.-C.; formal analysis, O.C.-L., H.A.L.-R. and G.D.M.; investigation, O.C.-L., P.D.-S., L.G.-G. and R.F.-R.; resources, H.A.L.-R.; data curation, H.A.L.-R., J.M.P.-R. and A.E.R.; writing-original draft preparation, H.A.L.-R. and A.E.R.; writing-review and editing, H.A.L.-R., J.A.R.-J. and A.E.R.; visualization, A.E.R.; supervision, G.D.M.; project administration, H.A.L.-R.; funding acquisition, H.A.L.-R. All authors have read and agreed to the published version of the manuscript.

Funding: This research received no external funding.

Institutional Review Board Statement: The study was conducted according to the guidelines of the Declaration of Helsinki. The Animal Care and Use Committee of the Veterinary and Animal Science Faculties from the Autonomous University of San Luis Potosí approved all procedures (no. 004/25022015), which complied with regulations established by the Animal Protection Law and Sanitary Regulations enacted by the State of San Luis Potosí, México.

Informed Consent Statement: Not applicable.

Data Availability Statement: The data presented in this study are available on request from the corresponding author. 
Acknowledgments: The first author thanks the Consejo Nacional de Ciencia y Tecnología (CONACYT) for his doctoral fellowship.

Conflicts of Interest: The authors declare no conflict of interest.

\section{References}

1. Mendoza-Martínez, G.D.; Pinos-Rodríguez, J.M.; Lee-Rangel, H.A.; Hernández-García, P.A.; Rojo-Rubio, R.; Relling, A. Effects of dietary calcium propionate on growth performance and carcass characteristics of finishing lambs. Anim. Prod. Sci. 2016, 56, 1194-1198. [CrossRef]

2. Liu, Q.; Wang, C.; Yang, W.Z.; Guo, G.; Yang, X.M.; He, D.C.; Huang, Y.X. Effects of calcium propionate supplementation on lactation performance, energy balance and blood metabolites in early lactation dairy cows. J. Anim. Physiol. Anim. Nutr. 2010, 94, 605-614. [CrossRef] [PubMed]

3. Aiello, R.J.; Armentano, L.E.; Bertics, S.J.; Murphy, A.T. Volatile fatty acid uptake and propionate metabolism in ruminant hepatocytes. J. Dairy Sci. 1989, 72, 942-949. [CrossRef]

4. Lee-Rangel, H.A.; Mendoza, G.D.; González, S.S. Effect of calcium propionate and sorghum level on lamb performance. Anim. Feed Sci. Technol. 2012, 177, 237-241. [CrossRef]

5. Martínez-Aispuro, J.; Sánchez-Torres, M.; Mendoza-Martínez, G.; Cordero Mora, J.; Figueroa-Velasco, J.; Ayala-Monter, M.; Crosby-Galván, M. Addition of calcium propionate to finishing lamb diets. Vet. Mex. 2019, 5, 37-46. [CrossRef]

6. Allen, M.S.; Bradford, B.J.; Harvatine, K.J. The cow as a model to study food intake regulation. Annu. Rev. Nutr. 2005, 25, 523-547. [CrossRef] [PubMed]

7. Steinhour, W.D.; Bauman, D.E. Propionate Metabolism: A New Interpretation. In Aspects of Digestive Physiology in Ruminants. In Proceedings of the Satellite Symposium of the 30th International Congress of the International Union of Physiological Sciences, Ithaca, NY, USA, 21-23 July 1986.

8. Sheperd, A.C.; Combs, D.K. Long-term effects of acetate and propionate on voluntary feed intake by midlactation cows. J. Dairy Sci. 1998, 81, 2240-2250. [CrossRef]

9. Oba, M.; Allen, M.S. Extent of hypophagia caused by propionate infusion is related to plasma glucose concentration in lactating dairy cows. Nutr. J. 2003, 133, 1105-1112. [CrossRef]

10. Henry, B.A. Links between the appetite regulating systems and the neuroendocrine hypothalamus: Lessons from the sheep. J. Neuroendocrinol. 2003, 15, 697-709. [CrossRef]

11. Relling, A.E.; Pate, J.L.; Reynolds, C.K.; Loerch, S.C. Effect of feed restriction and supplemental dietary fat on gut peptide and hypothalamic neuropeptide messenger ribonucleic acid concentrations in growing wethers. J. Anim. Sci. 2010, 88, 737-748. [CrossRef]

12. Valassi, E.; Scacchi, M.; Cavagnini, F. Neuroendocrine control of food intake. Nutr. Metab. Cardiovasc. 2008, 18, 158-168. [CrossRef]

13. Adam, C.L.; Archer, Z.A.; Findlay, P.A.; Thomas, L.; Marie, M. Hypothalamic gene expression in sheep for cocaine-and amphetamine-regulated transcript, pro-opiomelanocortin, neuropeptide $Y$, agouti-related peptide and leptin receptor and responses to negative energy balance. Neuroendocrinology 2002, 75, 250-256. [CrossRef]

14. Relling, A.E.; Lee, K.; Loerch, S.C.; Reynolds, C.K. Effects of glucose, propionate, and splanchnic hormones on neuropeptide mRNA concentrations in the ovine hypothalamus. J. Anim. Physiol. Anim. Nutr. 2012, 96, 648-654. [CrossRef]

15. AOAC. Official Methods of Analysis, 16th ed.; Association of Official Analytical Chemists: Rockville, MA, USA; The William Byrd Press Inc.: Richmond, VA, USA, 1990.

16. Van Soest, P.V.; Robertson, J.B.; Lewis, B.A. Methods for dietary fiber, neutral detergent fiber, and nonstarch polysaccharides in relation to animal nutrition. J. Dairy Sci. 1991, 74, 3583-3597. [CrossRef]

17. Inoue, H.; Watanuki, M.; Myint, H.T.; Ito, T.; Kuwayama, H.; Hidari, H. Effects of fasting and refeeding on plasma concentrations of leptin, ghrelin, insulin, growth hormone and metabolites in swine. Anim. Sci. J. 2005, 76, 367-374. [CrossRef]

18. Glass, D.J.; Amann, R.P.; Nett, T.M. Effects of season and sex on the distribution of cytosolic estrogen receptors within the brain and the anterior pituitary gland of sheep. Biol. Reprod. 1984, 30, 894-902. [CrossRef]

19. Judd, L.M.; Kohn, R.A. Test of conditions that affect in vitro production of volatile fatty acids and gases. J. Anim. Sci. 2018, 96, 694-704. [CrossRef]

20. Barham, D.; Trinder, P. An improved colour reagent for the determination of blood glucose by the oxidase system. Analyst 1972, 97, 142-145. [CrossRef] [PubMed]

21. Livak, K.J.; Schmittgen, T.D. Analysis of relative gene expression data using real-time quantitative PCR and the 2(-Delta Delta C(T)). Method 2001, 25, 402-408. [CrossRef]

22. Steel, G.D.; Torrie, R.; Dickey, D.A. Principles and Procedures of Statistics: A Biometrical Approach; McGraw-Hill: New York, NY, USA, 1997.

23. National Research Council. Nutrient Requirements of Small Ruminants: Sheep, Goats, Cervids, and New World Camelids; The National Academies Press: Washington, DC, USA, 2007.

24. Forbes, J. Voluntary Food Intake and Diet Selection in Farm Animals, 2nd ed.; CABI: Wallingford, UK, 2007.

25. Yao, Q.; Li, Y.; Meng, Q.; Zhou, Z. The effect of calcium propionate on the ruminal bacterial community composition in finishing bulls. Asian-Australas. J. Anim. Sci. 2017, 30, 495-504. [CrossRef] [PubMed] 
26. Bradford, B.J.; Allen, M.S. Phlorizin administration does not attenuate hypophagia induced by intraruminal propionate infusion in lactating dairy cattle. Nutr. J. 2007, 137, 326-330. [CrossRef]

27. McNamara, J.P.; Valdez, F. Adipose tissue metabolism and production responses to calcium propionate and chromium propionate. J. Dairy Sci. 2005, 88, 2498-2507. [CrossRef]

28. Beem, A.E. Use of Urine $\mathrm{pH}$ to Predict Incidence of Ketosis in Transition Dairy Cows. Master's Thesis, Louisiana State University, Baton Rouge, LA, USA, 2003.

29. DeFrain, J.M.; Hippen, A.R.; Kalscheur, K.F.; Jardon, P.W. Feeding glycerol to transition dairy cows: Effects on blood metabolites and lactation performance. J. Dairy Sci. 2004, 87, 4195-4206. [CrossRef]

30. Zhang, X.Z.; Meng, Q.X.; Lu, L.; Cui, Z.L.; Ren, L.P. The effect of calcium propionate supplementation on performance, meat quality, and mRNA expression of finishing steers fed a high-concentrate diet. J. Anim. Feed Sci. 2015, 663, 127. [CrossRef]

31. Stocks, S.E.; Allen, M.S. Hypophagic effects of propionic acid are not attenuated during a 3-day infusion in the early postpartum period in Holstein cows. J. Dairy Sci. 2013, 96, 4615-4623. [CrossRef] [PubMed]

32. Reynolds, C.K.; Aikman, P.C.; Lupoli, B.; Humphries, D.J.; Beever, D.E. Splanchnic metabolism of dairy cows during the transition from late gestation through early lactation. J. Dairy Sci. 2003, 86, 1201-1217. [CrossRef]

33. Fellner, V.; Spears, J.W. Effect of Calcium Propionate on Ruminal Soluble Calcium and Microbial Fermentation; Animal Science Departmental Report; North Carolina State University: Raleigh, NC, USA, 2005.

34. Grilli, D.; Egea, V.; Paez-Lama, S.; Carcaño, D.; Allegretti, L.; Sosa-Escudero, M.; Arenas, G.N. Degradation and utilization of hemicellulose from species forage by Pseudobutyrivibrio ruminis and Pseudobutyrivibrio xylanivorans. Rev. Fac. Cienc. Agrar. UNCuyo 2015, 47, 231-243.

35. Miranda, L.A.; Lee-Rangel, H.A.; Mendoza-Martínez, G.D.; Crosby-Galván, M.M.; Relling, A.E.; Pinos-Rodríguez, J.M.; Rubio, R.R.; Hernandez, M.G. Influence of calcium propionate on in vitro fermentation of sorghum-based diets. Rev. Fac. Cienc. Agrar. UNCuyo 2017, 49, 185-192.

36. Jean, B.E. Effect of Calcium Supplementation on Ruminal Soluble Calcium Concentrations and Ruminal Fermentation. Master's Thesis, North Carolina State University, Raleigh, NC, USA, 2005; p. 58.

37. Rodrigues, J.P.P.; de Paula, R.M.; Rennó, L.N.; Fontes, M.M.S.; Machado, A.F.; Valadares Filho, S.C.; Huhtanen, P.; Marcondes, M.I. Short-term effects of soybean oil supplementation on performance, digestion, and metabolism in dairy cows fed sugarcane-based diets. Int. J. Dairy Sci. 2017, 100, 4435-4447. [CrossRef] [PubMed]

38. Lemosquet, S.; Delamaire, E.; Lapierre, H.; Blum, J.W.; Peyraud, J.L. Effects of glucose, propionic acid, and nonessential amino acids on glucose metabolism and milk yield in Holstein dairy cows. Int. J. Dairy Sci. 2009, 92, 3244-3257. [CrossRef]

39. Oh, Y.K.; Eun, J.S.; Lee, S.C.; Chu, G.M.; Lee, S.S.; Moon, Y.H. Responses of blood glucose, insulin, glucagon, and Fatty acids to intraruminal infusion of propionate in hanwoo. Asian-Australas. J. Anim. Sci. 2015, 28, 200-206. [CrossRef]

40. Whitlock, B.K.; Daniel, J.A.; McMahon, C.D.; Buonomo, F.C.; Wagner, C.G.; Steele, B.; Sartin, J.L. Intracerebroventricular melanin-concentrating hormone stimulates food intake in sheep. Domest. Anim. Endocrinol. 2005, 28, 224-232. [CrossRef] [PubMed]

41. Miner, J.L.; Della-Fera, M.A.; Paterson, J.A. Blockade of satiety factors by central injection of neuropeptide Y in sheep. J. Anim. Sci. 1990, 68, 3805-3811. [CrossRef] [PubMed]

42. Mayer, J. Glucostatic mechanism of regulation of food intake. N. Engl. J. Med. 1953, 249, 13-16. [CrossRef]

43. Schwartz, M.W.; Sipols, A.J.; Marks, J.L.; Sanacora, G.; White, J.D.; Scheurink, A.; Kahn, S.E.; Baskin, D.G.; Woods, S.C.; Figlewicz, D. Inhibition of hypothalamic neuropeptide Y gene expression by insulin. Endocrinology 1992, 130, 3608-3616. [CrossRef]

44. Archer, Z.A.; Findlay, P.A.; McMillen, S.R.; Rhind, S.M.; Adam, C.L. Effects of nutritional status and gonadal steroids on expression of appetite-regulatory genes in the hypothalamic arcuate nucleus of sheep. Int. J. Endocrinol. 2004, 182, 409-420. [CrossRef] [PubMed]

45. Iqbal, J.; Pompolo, S.; Dumont, L.M.; Wu, C.S.; Mountjoy, K.G.; Henry, B.A.; Clarke, I.J. Long-term alterations in body weight do not affect the expression of melanocortin receptor-3 and-4 mRNA in the ovine hypothalamus. Neuroscience 2001, 105, 931-940. [CrossRef]

46. Wagner, C.G.; McMahon, C.D.; Marks, D.L.; Daniel, J.A.; Steele, B.; Sartin, J.L. A role for agouti-related protein in appetite regulation in a species with continuous nutrient delivery. Neuroendocrinology 2004, 80, 210-218. [CrossRef]

47. Sartin, J.L.; Daniel, J.A.; Whitlock, B.K.; Wilborn, R.R. Selected hormonal and neurotransmitter mechanisms regulating feed intake in sheep. Animal 2010, 4, 1781-1789. [CrossRef] 